\title{
Subject Index Vol. 44, 2010
}

\section{Ophthalmic Research}

Actinomycin D 225

Age-related cataract 155, 191

- macular degeneration 131, 191, 237

Aging 34, 146, 173

Allergic conjunctivitis 119

Alloplast 50

Antifungal drugs 113

Antimetabolites 205

Antioxidants 166

Apoptosis 43, 199

Aspergillus 251

- flavus 251

Avastin 205

Axial length 242

Bevacizumab 43, 205

Black-currant extract 242

Calorie restriction 146

Candida albicans 251

Cat 82

Cataract 166

Cell culture 82

- senescence 199

Chemokine 24

Chick 242

Choroidal neovascular membrane 237

Corneal endothelial cells 43

Corticosteroids 205

Cytokine 24

Disulfiram 225

Dog 82

Drug-induced secondary cataract prevention 225

Dry eye 146

Electron microscopy 82

Electroretinogram 82

Vol. 44, No. 3, 2010 has its own Subject Index.

Endothelium 125

Experimental animal model 119

- autoimmune uveitis, rat 24

Extraocular muscle surgery 50

Fetus 125

Free radicals 191

Fusarium solani 251

Ganglion cell injury 173

Glaucoma 173

Glutamate 105

Histology 82

Human meibum 34

Hypoxia 105

Immunohistochemistry 82

Indocyanine green 17

Infrared spectroscopy 34

Intravitreal morphometry 82

Irish Longitudinal Study on Ageing 131

$\beta$-Lactoglobulin 119

Lens-induced myopia 242

Lipids 34

Lucentis 205

Macular pigment optical density 131

Methotrexate 225

Micronutrients 166

Microplasmin 205

Mitochondria 179

Monoclonal antibodies 205

Mouse 82

Müller cell 105

Mycotic keratitis 113
$\mathrm{Na}^{+}-\mathrm{K}^{+}$-adenosine triphosphatase 43

Nested PCR 251

Nonhuman primates 82

Nonsteroidal anti-inflammatory drugs 205

Ocular disease 166

- function 179

Oral administration 242

Oxidative damage 155

- stress 166

Pharmacotherapy 82

Pig 82

Proteinase assay 113

Rabbit 82

Ranibizumab 205

Reactive oxygen species 146,179

Retina 105, 125, 205

Retinal aging 199

RTL, treatment 24

Sensitivity tests 113

Sirtuin 199

Taurine 105

Tears 34

Tight junctions 43

Toll-like receptor 3237

Triamcinolone 17, 205

Trypan blue 17

Tumor necrosis factor 205

Vascular endothelial growth factor 125 , 205 